Article

\title{
Synthesis, Crystal Structure, and Luminescent Property of a Cd(II) Coordination Polymer with a $N$-Nicotinoylglycine Ligand
}

\author{
Xi-Shi Tai ${ }^{1, *}$, Xin Wang ${ }^{2}$ and Peng-Fei $\mathrm{Li}^{3}$ \\ College of Chemistry and Chemical Engineering, Weifang University, Weifang 261061, China \\ 2 Department of Chemistry, Qinghai Normal University, Xining 810008, China; wxfighting@126.com \\ 3 College of Chemical Engineering, Qingdao University of Science and Technology, Qingdao 266061, China; \\ lipfei2013@163.com \\ * Correspondence: taixs@wfu.edu.cn; Tel.: +86-536-8785363
}

Academic Editor: Helmut Cölfen

Received: 6 December 2016; Accepted: 23 January 2017; Published: 25 January 2017

\begin{abstract}
A new 1D Cd(II) coordination polymer, $\left[\left\{\mathrm{CdL}_{2}\left(\mathrm{H}_{2} \mathrm{O}\right)\right\} \cdot\left(\mathrm{H}_{2} \mathrm{O}\right)_{3}\right]_{n}(\mathrm{HL}=N$-nicotinoylglycine $)$, has been synthesized by the assembly of $\mathrm{Cd}\left(\mathrm{NO}_{3}\right)_{2} \cdot 4 \mathrm{H}_{2} \mathrm{O}$ with $\mathrm{N}$-nicotinoylglycine, and its composition was determined by elemental analysis, infrared, and X-ray single-crystal diffraction analysis. In this complex, the $\mathrm{Cd}$ (II) is seven-coordinated by two $\mathrm{N}$ atoms of two $\mathrm{N}$-nicotinoylglycine anions, four $\mathrm{O}$ atoms of two $\mathrm{N}$-nicotinoylglycine anions, and one $\mathrm{O}$ atom of a coordinated water molecule. The complex forms a 1D looped coordination polymer by the bridging of the $\mathrm{N}$-nicotinoylglycine anion. The luminescent property of the $\mathrm{N}$-nicotinoylglycine ligand and the $\mathrm{Cd}$ (II) coordination polymer has also been studied.
\end{abstract}

Keywords: $N$-nicotinoylglycine; $\mathrm{Cd}(\mathrm{II})$ coordination polymer; synthesis; crystal structure; luminescence

\section{Introduction}

Metal-organic coordination polymers have received great attention as an important part of coordination chemistry. Many of them that are constructed by $\mathrm{Cd}$ (II) ions or bridging multipodal ligands show unique structures and excellent properties in gas storage, luminescence, catalysis, and magnetism [1-7]. In the past decades, many multipodal ligands containing two $-\mathrm{COO}^{-}$functional groups and neutral ligands, such as 4,4'-bipyridine and 1,10-phenanthroline, have been chosen to build coordination polymers [8-13]. Recently, our group has obtained some new $\mathrm{Cd}(\mathrm{II}), \mathrm{Ca}(\mathrm{II}), \mathrm{Mg}$ (II), and $\mathrm{Zn}(\mathrm{II})$ coordination polymer materials and have investigated their structures and properties [14-18]. In order to investigate the coordination behavior of ligands containing both $-\mathrm{COO}^{-}$and pyridine bifunctional groups and the property of their metal complexes, herein, a new $1 \mathrm{D} \mathrm{Cd}(\mathrm{II})$ coordination polymer, $\left[\left\{\mathrm{CdL}_{2}\left(\mathrm{H}_{2} \mathrm{O}\right)\right\} \cdot\left(\mathrm{H}_{2} \mathrm{O}\right)_{3}\right]_{\mathrm{n}}(\mathrm{HL}=\mathrm{N}$-nicotinoylglycine $)$ has been synthesized and its luminescent property in the solid state has also been investigated. The chemical diagram of the $\mathrm{Cd}(\mathrm{II})$ complex is shown in Scheme 1. 


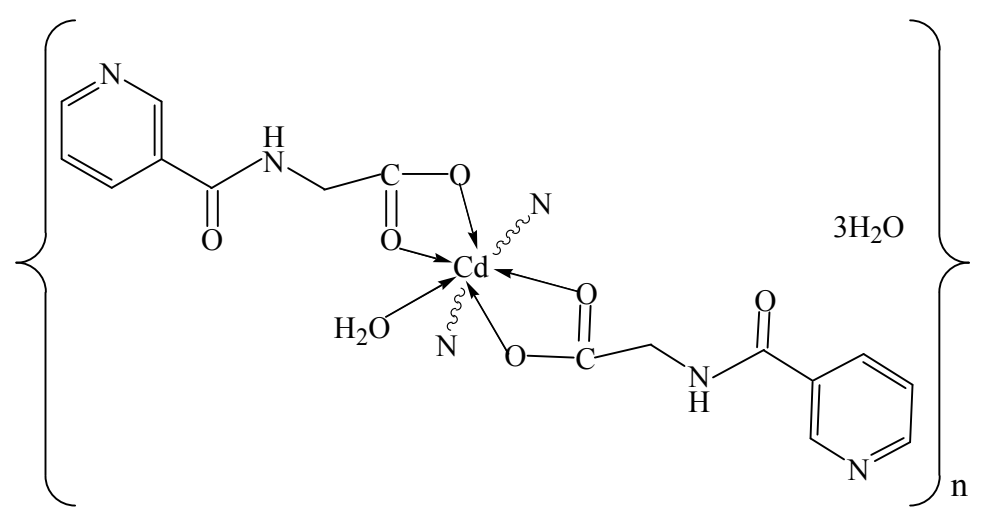

Scheme 1. Chemical diagram of the Cd(II) complex.

\section{Results and Discussion}

\subsection{Characterization of $\left[\left\{\mathrm{CdL}_{2}\left(\mathrm{H}_{2} \mathrm{O}\right)\right\} \cdot\left(\mathrm{H}_{2} \mathrm{O}\right)_{3}\right]_{n}$}

A comparison of the $N$-nicotinoylglycine ligand and $\mathrm{Cd}(\mathrm{II})$ complex was conducted with infrared data, and the ligand shows two characteristic absorption bands at $1725 \mathrm{~cm}^{-1}\left(v\left(\mathrm{COO}^{-}\right)\right)$and $1634 \mathrm{~cm}^{-1}(v(\mathrm{C}(\mathrm{O})-\mathrm{NH}))$, and at $1675 \mathrm{~cm}^{-1}\left(\nu\left(\mathrm{COO}^{-}\right)\right)$and $1636 \mathrm{~cm}^{-1}(\nu(\mathrm{C}(\mathrm{O})-\mathrm{NH}))$, respectively. The shift of $\mathrm{COO}^{-}$is $50 \mathrm{~cm}^{-1}$, indicating that the oxygen atom of the $\mathrm{COO}^{-}$group coordinated to $\mathrm{Cd}(\mathrm{II})$. However, The shift of $\mathrm{C}(\mathrm{O})-\mathrm{NH}$ is $2 \mathrm{~cm}^{-1}$, indicating that the oxygen atom of the $\mathrm{C}(\mathrm{O})-\mathrm{NH}$ group does not coordinate to $\mathrm{Cd}(\mathrm{II})$. The band at $3256 \mathrm{~cm}^{-1}$ proves that the $\mathrm{Cd}(\mathrm{II})$ complex contains water molecules [19].

\subsection{Structural Description of $\left[\left\{\mathrm{CdL}_{2}\left(\mathrm{H}_{2} \mathrm{O}\right)\right\} \cdot\left(\mathrm{H}_{2} \mathrm{O}\right)_{3}\right]_{n}$}

The coordination environment of the $\mathrm{Cd}(\mathrm{II})$ ion in $\left[\left\{\mathrm{CdL}_{2}\left(\mathrm{H}_{2} \mathrm{O}\right)\right\} \cdot\left(\mathrm{H}_{2} \mathrm{O}\right)_{3}\right]_{\mathrm{n}}$ is shown in Figure 1. Selected bond distances and bond angles are given in Table 1. Its crystal structure shows that each Cd(II) ion is seven-coordinated by four $\mathrm{O}$ atoms from two carboxyl group of two different $\mathrm{N}$-nicotinoylglycine anion ligands, two $\mathrm{N}$ atoms from two different $\mathrm{N}$-nicotinoylglycine anion ligands, and one $\mathrm{O}$ atom from a coordinated water molecule. Each Cd(II) ion adopts a distorted pengonal bipyramidal coordination environment. The carboxyl groups of $N$-nicotinoylglycine anion ligands adopt a didentate coordination mode in the complex molecule. The distances of $\mathrm{Cd} \cdot \mathrm{Cd}$ separated by $\mathrm{N}$-nicotinoylglycine anion ligands are $10.064 \AA$ and $9.933 \AA$, respectively.

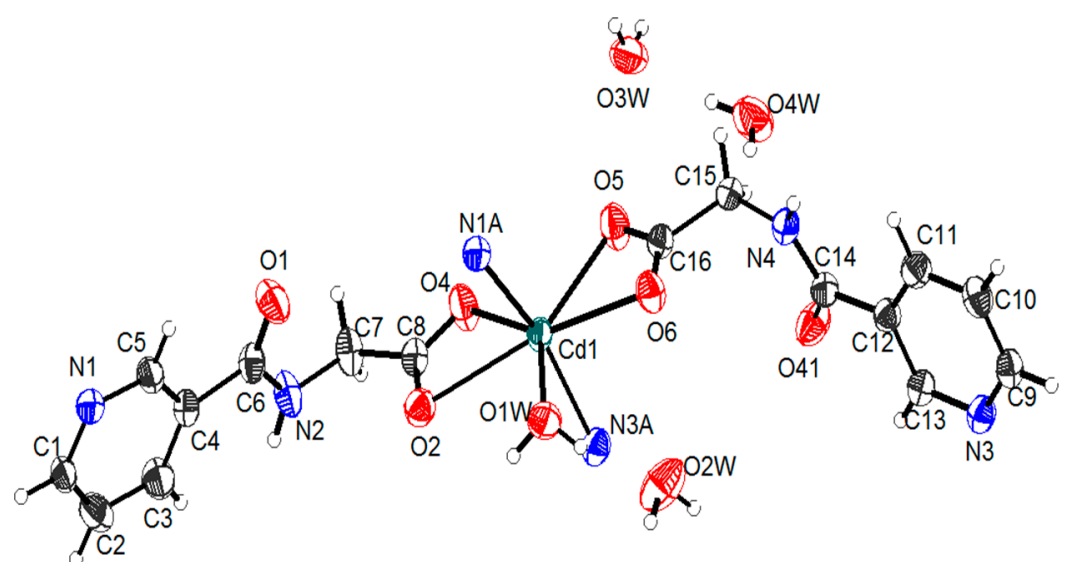

Figure 1. The coordination environment of the $\mathrm{Cd}(\mathrm{II})$ ion. 
Table 1. Selected bond lengths $d(\AA)$ and bond angles $\left(^{\circ}\right)$ for $\left[\left\{\mathrm{CdL}_{2}\left(\mathrm{H}_{2} \mathrm{O}\right)\right\} \cdot\left(\mathrm{H}_{2} \mathrm{O}\right)_{3}\right]_{\mathrm{n}}$.

\begin{tabular}{|c|c|c|c|}
\hline Bond & $d$ & Bond & $d$ \\
\hline Cd1-O4 & $2.283(3)$ & Cd1-O6 & $2.337(3)$ \\
\hline Cd1-N1 ${ }^{\mathrm{i}}$ & $2.357(3)$ & Cd1-O1W & $2.361(3)$ \\
\hline Cd1-N3 ${ }^{\text {ii }}$ & $2.370(3)$ & Cd1-O5 & $2.493(3)$ \\
\hline $\mathrm{Cd} 1-\mathrm{O} 2$ & $2.609(3)$ & C6-O1 & $1.222(5)$ \\
\hline $\mathrm{C} 8-\mathrm{O} 2$ & $1.229(5)$ & $\mathrm{C} 8-\mathrm{O} 4$ & $1.267(5)$ \\
\hline C16-O5 & $1.251(5)$ & O6-C16 & $1.234(5)$ \\
\hline C1-N1 & $1.337(5)$ & C5-N1 & $1.336(5)$ \\
\hline C6-N2 & $1.330(5)$ & N2-C7 & $1.441(5)$ \\
\hline N3-C13 & $1.331(5)$ & N3-C9 & $1.350(5)$ \\
\hline N4-C14 & $1.327(5)$ & N4-C15 & $1.442(5)$ \\
\hline C16-C15 & $1.517(5)$ & C2-C1 & $1.378(6)$ \\
\hline C3-C2 & $1.383(6)$ & C4-C3 & $1.385(5)$ \\
\hline C4-C5 & $1.380(5)$ & C4-C6 & $1.501(5)$ \\
\hline C7-C8 & $1.528(5)$ & C9-C10 & $1.383(6)$ \\
\hline C10-C11 & $1.379(6)$ & C11-C12 & $1.389(5)$ \\
\hline Angle & $\omega$ & Angle & $\omega$ \\
\hline O4-Cd1-O6 & $138.27(11)$ & O4-Cd1-N1 ${ }^{\mathrm{i}}$ & $94.26(12)$ \\
\hline O6-Cd1-N1 i & $94.80(11)$ & O4-Cd1-O1W & $138.23(11)$ \\
\hline O6-Cd1-O1W & 83.50(11) & O1W-Cd1-N1 ${ }^{\mathrm{i}}$ & 79.14(12) \\
\hline $\mathrm{O} 4-\mathrm{Cd} 1-\mathrm{N} 3{ }^{\mathrm{ii}}$ & $95.42(12)$ & O6-Cd1-N3 ${ }^{\text {ii }}$ & $87.58(11)$ \\
\hline $\mathrm{N} 1{ }^{\mathrm{i}}-\mathrm{Cd} 1-\mathrm{N} 3{ }^{\mathrm{ii}}$ & $162.55(12)$ & $\mathrm{O} 1 \mathrm{~W}-\mathrm{Cd} 1-\mathrm{N} 3$ ii & $83.98(11)$ \\
\hline O5-Cd1-O4 & $84.67(11)$ & O5-Cd1-O6 & $53.62(10)$ \\
\hline $\mathrm{N} 1{ }^{\mathrm{i}}-\mathrm{Cd} 1-\mathrm{O} 5$ & 100.70(12) & O5-Cd1-O1W & $137.09(10)$ \\
\hline N3 ${ }^{\text {ii_-Cd1-O5 }}$ & $94.63(12)$ & O4-Cd1-O2 & $52.62(10)$ \\
\hline O6-Cd1-O2 & $168.53(10)$ & $\mathrm{O} 2-\mathrm{Cd} 1-\mathrm{N} 1{ }^{\mathrm{i}}$ & $86.89(11)$ \\
\hline O1W-Cd1-O2 & $85.69(10)$ & $\mathrm{O} 2-\mathrm{Cd} 1-\mathrm{N} 3{ }^{\mathrm{ii}}$ & $87.49(11)$ \\
\hline O5-Cd1-O2 & $137.20(10)$ & & \\
\hline
\end{tabular}

In the crystal, the looped structure is formed by the bridging of $N$-nicotinoylglycine anion ligands (Figure 2). The 3D network is generated by $\pi \cdots \pi$ stacking and hydrogen bond interactions (Figure 3 ).

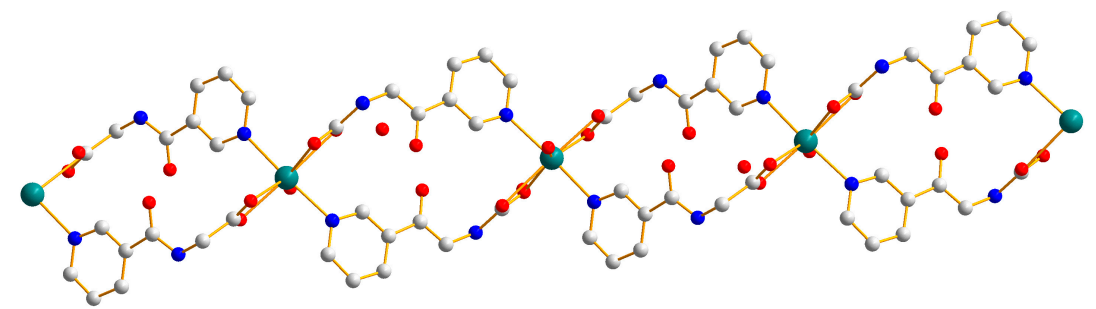

Figure 2. One-dimensional chained structure by the bridging of ligands.

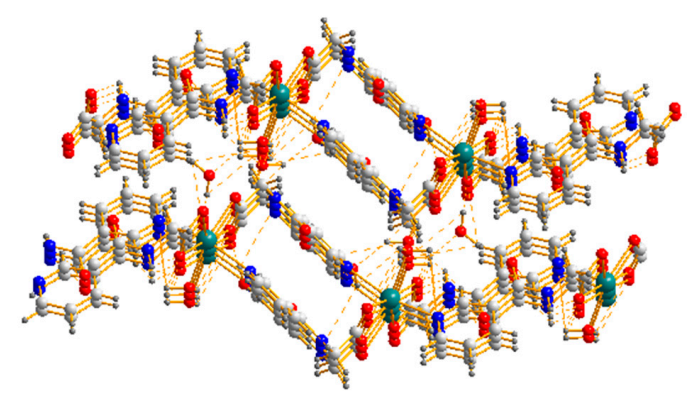

Figure 3. 3D supramolecular network structure. 


\subsection{Luminescent Property}

The luminescent behaviors of $\left[\left\{\mathrm{CdL}_{2}\left(\mathrm{H}_{2} \mathrm{O}\right)\right\} \cdot\left(\mathrm{H}_{2} \mathrm{O}\right)_{3}\right]_{\mathrm{n}}$ and the free ligand are investigated in the solid state on a multicrystalline bulk sample. The luminescent spectrum of the $\mathrm{Cd}(\mathrm{II})$ coordination polymer is shown in Figure 4. The Cd(II) coordination polymer shows a luminescent peak at $458 \mathrm{~nm}$ when excited at $358 \mathrm{~nm}$, however, the $\mathrm{N}$-nicotinoylglycine ligand does not have a luminescent peak. Thus, the luminescent emission of the Cd(II) coordination polymer may be due to the charge transfer of ligand-to-metal [20].

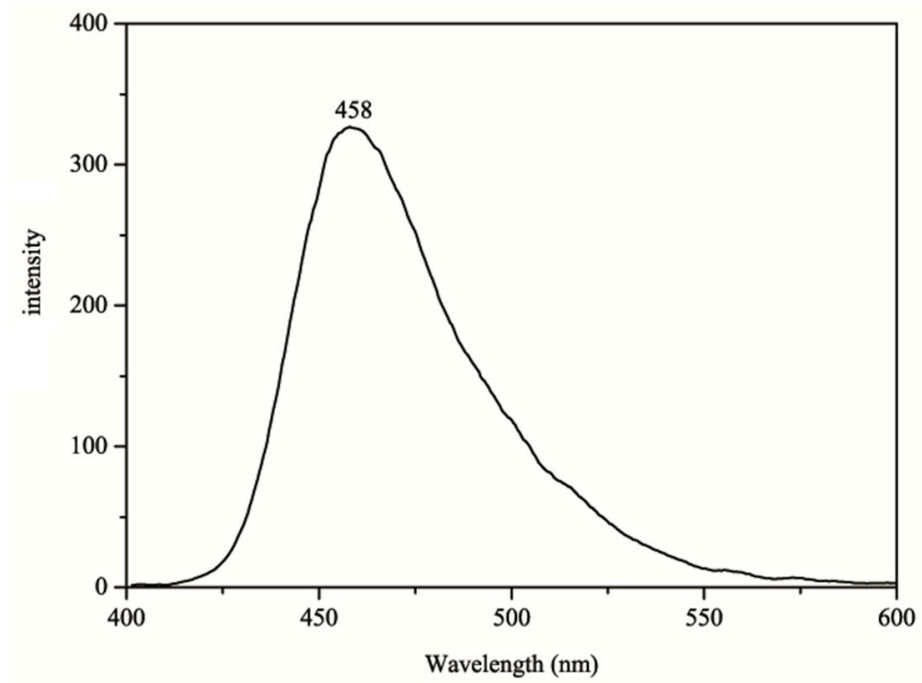

Figure 4. The luminescent spectrum of the Cd(II) coordination polymer.

\section{Experimental Section}

\subsection{Materials and Instrumentation}

$\mathrm{N}$-nicotinoylglycine and $\mathrm{Cd}\left(\mathrm{NO}_{3}\right)_{2} \cdot 4 \mathrm{H}_{2} \mathrm{O}$ were purchased from Xi'ya Chemical Reagent Company and used as received. $\mathrm{C}, \mathrm{H}$, and $\mathrm{N}$ were determined on a Elementar Vario III EL elemental analyzer (Hanau, Germany). IR spectra were recorded on a Nicolet AVATAR 360 FTIR spectrophotometer (Nicolet Instrument Inc., Madison, WI, USA) (range $4000 \mathrm{~cm}^{-1} \sim 400 \mathrm{~cm}^{-1}$ ) as $\mathrm{KBr}$ discs. Crystal structure of $\left[\left\{\mathrm{CdL}_{2}\left(\mathrm{H}_{2} \mathrm{O}\right)\right\} \cdot\left(\mathrm{H}_{2} \mathrm{O}\right)_{3}\right]_{\mathrm{n}}$ was determined on a Bruker Smart CCD diffractometer (Bruker, Billerica, MA, USA). Luminescent spectra were recorded on a PE LS-55 spectrometer (PerkinElmer, Billerica, MA, USA).

\subsection{Synthesis of $\left[\left\{\mathrm{CdL}_{2}\left(\mathrm{H}_{2} \mathrm{O}\right)\right\} \cdot\left(\mathrm{H}_{2} \mathrm{O}\right)_{3}\right]_{n}$}

A $\mathrm{CH}_{3} \mathrm{CH}_{2} \mathrm{OH} / \mathrm{H}_{2} \mathrm{O}(v: v=3: 1)$ solution of $N$-nicotinoylglycine $(0.1802 \mathrm{~g}, 1.0 \mathrm{mmol})$ and $\mathrm{NaOH}$ $(0.040 \mathrm{~g}, 1.0 \mathrm{mmol})$ was stirred to clarify, then a water solution $(3 \mathrm{~mL})$ of $\mathrm{Cd}\left(\mathrm{NO}_{3}\right)_{2} \cdot 4 \mathrm{H}_{2} \mathrm{O}(0.3085 \mathrm{~g}$, $1.0 \mathrm{mmol}$ ) was added to the above mixture. The mixture was stirred for $5 \mathrm{~h}$ at $60{ }^{\circ} \mathrm{C}$ and filtered. Colorless crystals suitable were obtained after 10 days by evaporation at room temperature. Yield $52 \%$. Anal. Calcd. for $\mathrm{C}_{16} \mathrm{H}_{22} \mathrm{~N}_{4} \mathrm{O}_{10} \mathrm{Cd}$ : C, 35.37; H, 4.05; N, 10.32. Found: $\mathrm{C}, 35.15 ; \mathrm{H}, 4.47 ; \mathrm{N}, 10.11$. IR $v_{\max }\left(\mathrm{cm}^{-1}\right): v\left(\mathrm{H}_{2} \mathrm{O}\right): 3256 \mathrm{~cm}^{-1}, v\left(\mathrm{COO}^{-}\right): 1675 \mathrm{~cm}^{-1}, v(\mathrm{C}(\mathrm{O})-\mathrm{NH}): 1636 \mathrm{~cm}^{-1}$.

\subsection{Crystal Structure Determination}

Crystal data of $\left[\left\{\mathrm{CdL}_{2}\left(\mathrm{H}_{2} \mathrm{O}\right)\right\} \cdot\left(\mathrm{H}_{2} \mathrm{O}\right)_{3}\right]_{\mathrm{n}}$ were collected on a Bruker Smart APEX CCD diffractometer at $293(2) \mathrm{K}$ using graphite-monochromated $\mathrm{MoK} \alpha$ radiation $(\lambda=0.71073 \AA)$. The structure was solved by direct method using the SHELX program [21], and refined by full-matrix 
least squares on $F^{2}$ using the SHELXL program [22]. Technical details of the crystal structure solutions and refinements are listed in Table 2.

Table 2. Crystallographic data and structure refinement for $\left[\left\{\mathrm{CdL}_{2}\left(\mathrm{H}_{2} \mathrm{O}\right)\right\} \cdot\left(\mathrm{H}_{2} \mathrm{O}\right)_{3}\right]_{\mathrm{n}}$.

\begin{tabular}{cc}
\hline Empirical Formula & $\mathbf{C}_{\mathbf{1 6}} \mathbf{H}_{\mathbf{2 2}} \mathbf{N}_{\mathbf{4}} \mathbf{O}_{\mathbf{1 0}} \mathbf{C d}$ \\
\hline Formula weight & 542.77 \\
Temperature/K & $293(2)$ \\
Crystal system & Triclinic \\
Space group & $P-1$ \\
$a / \AA$ & $8.3460(17)$ \\
$b / \AA$ & $8.5186(17)$ \\
$c / \AA$ & $16.727(3)$ \\
$\alpha /{ }^{\circ}$ & $100.90(3)$ \\
$\beta /{ }^{\circ}$ & $94.89(3)$ \\
$\gamma /{ }^{\circ}$ & $116.16(3)$ \\
Volume/ $\AA^{3}$ & $1028.8(4)$ \\
$Z$ & 2 \\
$\rho_{\text {calc }}$ mg/mm & \\
$\mu /$ mm $^{-1}$ & 1.752 \\
$S$ & 1.124 \\
$F(000)$ & 1.211 \\
& 548 \\
Index ranges & $-10 \leq h \leq 10$, \\
Reflections collected & $-11 \leq k \leq 11$, \\
Independent reflections & $-21 \leq l \leq 18$ \\
Data/restraints $/$ parameters & 9521 \\
Goodness-of-fit on $F^{2}$ & $4531[R($ int $)=0.0293]$ \\
Final $R$ indexes $[I>=2 \sigma(I)]$ & $4531 / 14 / 304$ \\
Final $R$ indexes [all data] & 1.212 \\
Largest diff. peak/hole/e. $\AA^{-3}$ & $R_{1}=0.0381, w R_{2}=0.1024$ \\
\hline & $R_{1}=0.0442, w R_{2}=0.1055$ \\
& $1.460 /-0.598$ \\
\hline &
\end{tabular}

\section{Conclusions}

In summary, $\left[\left\{\mathrm{CdL}_{2}\left(\mathrm{H}_{2} \mathrm{O}\right)\right\} \cdot\left(\mathrm{H}_{2} \mathrm{O}\right)_{3}\right]_{\mathrm{n}}$ has been prepared and characterized by elemental analysis, infrared, and $\mathrm{X}$-ray single-crystal diffraction analysis. The $\mathrm{Cd}(\mathrm{II})$ complex forms a $1 \mathrm{D}$ helix coordination polymer by the bridging of the $N$-nicotinoylglycine anion. The 3D network is generated by $\pi \cdots \pi$ stacking interactions. The luminescent property of the $N$-nicotinoylglycine ligand and the $\mathrm{Cd}(\mathrm{II})$ coordination polymer has also been studied.

Acknowledgments: This project was supported by the National Natural Science Foundation of China (No. 21171132), the National Natural Science Foundation of Shandong (ZR2014BL003), the Project of Shandong Province Higher Educational Science and Technology Program (J14LC01) and Science Foundation of Weifang.

Author Contributions: Tai Xi-Shi designed the method and wrote the manuscript. Wang Xin synthesized the $\mathrm{Cd}(\mathrm{II})$ coordination polymer. Li Peng-Fei analysed the crystal data of $\mathrm{Cd}(\mathrm{II})$ coordination polymer.

Conflicts of Interest: The authors confirm that this article content has no conflict of interest.

\section{Appendix A}

Crystallographic data for the structure reported in this paper has been deposited with the Cambridge Crystallographic Data Centre as supplementary publication No. CCDC 1470820. Copy of the data can be obtained free of charge on application to CCDC, 12 Union Road, Cambridge CB2 1EZ, UK (Fax: +44-1223-336-033; E-Mail: deposit@ccdc.cam.ac.uk). 


\section{References}

1. Yu, X.Y.; Zhang, X.; Qu, X.S.; Ma, M.S.; Liu, Z.G.; Jin, L.; Yang, Y.Y.; Luo, Y.N. A new 3D Cd(II) coordination polymer with metallacalix[4]arene building blocks based on 2-(pyridine-2-yl)-1H-imidazole-4,5-dicarboxylic acid. J. Coord. Chem. 2015, 68, 3580-3588. [CrossRef]

2. Hazari, D.; Jana, S.K.; Puschmann, H.; Zangrando, E.; Dalai, S. Three new Coordination polymers of zinc(II) and cadmium(II) with dicarboxylate and bipyridine ligands: Synthesis, structure and luminescence study. J. Inorg. Organomet. Polym. Mater. 2015, 25, 1151-1159. [CrossRef]

3. Yang, L.R.; Liu, L.; Lian, C.; Liu, M.Y.; Xu, Z.H.; Wang, L.C.; Guo, X.; Long, Y.S. Zero-, one-, two-, and three-dimensional coordination polymers based on tetracarboxylic acid: Syntheses, structures, magnetic and luminescent properties. Dyes Pigments 2015, 122, 246-256. [CrossRef]

4. Yoon, M.; Moon, D. New $\mathrm{Zr}(\mathrm{IV})$ based metal-organic framework comprising a sulfur-containing ligand: Enhancement of $\mathrm{CO}_{2}$ and $\mathrm{H}_{2}$ storage capacity. Microporous Mesoporous Mater. 2015, 215, 116-122. [CrossRef]

5. Wang, X.L.; Luan, J.; Lin, H.Y.; Liu, G.C.; Le, M. Four cobalt(II) coordination polymers based on a flexible $N, N^{\prime}$-bis(3-pyridinecarboxamide)-1,6-hexane ligand: Modulation of crystal architectures through the substituent groups of isophthalates. Polyhedron 2014, 71, 111-118. [CrossRef]

6. Saravanakumar, R.; Varghese, B.; Sankararaman, S. Isostructural 1D coordination polymers of $\mathrm{Zn}$ (II), Cd(II) and $\mathrm{Cu}(\mathrm{II})$ with phenylpropynoic acid and DABCO as organic linkers. J. Mol. Struct. 2014, 1076, 280-284. [CrossRef]

7. Bajpai, A.; Chandrasekhar, P.; Govardhan, S.; Banerjee, R.; Moorthy, J.N. Single crystal-to-single crystal site-selective postsynthetic metal exchange in a $\mathrm{Zn}-\mathrm{MOF}$ based on semi-rigid tricarboxylic acid and access to bimetallic MOFs. Chem. Eur. J. 2015, 21, 2759-2765. [CrossRef] [PubMed]

8. Yang, Y.X.; Li, H.Y.; Wu, J.F. Synthesis and crystal structures of inclusion compounds of 2,2'-dithiosalicylic acid and triethylamine/tripropylamine. Crystallogr. Rep. 2015, 60, 1006-1012. [CrossRef]

9. Guo, X.H.; Zhang, X.; Zhao, L.Y.; Zhang, N.X.; Yi, Z.H. Synthesis and crystal structure of cadmium coordination polymer with 1,3,5-benzenetricarboxylic acid. Crystallogr. Rep. 2015, 60, 860-864. [CrossRef]

10. Zhang, J.W.; Kan, X.M.; Li, X.L.; Liu, Y.; Liu, B.Q. A series of copper-lanthanide heterometallic coordination polymers derived from pyridine-2,3-dicarboxylic acid and in situ generated succinic acid. Eur. J. Inorg. Chem. 2016, 2016, 1060-1067. [CrossRef]

11. Guo, X.M.; Yan, Y.N.; Guo, H.D.; Wang, N.; Qi, Y.J. Construction of two novel coordination polymers from a V-shaped bisimidazole ligand: Synthesis, characterization and properties. Inorg. Chem. Commun. 2016, 64, 59-62. [CrossRef]

12. Li, T.; Huang, X.H.; Zhao, Y.F.; Li, H.H.; Wu, S.T.; Huang, C.C. An unusual double T5(2) water tape trapped in silver(I) coordination polymer hosts: Influence of the solvent on the assembly of $\mathrm{Ag}(\mathrm{I})-4,4^{\prime}$-bipyridine chains with trans-cyclohexanedicarboxylate and their luminescent properties. Dalton Trans. 2012, 41, 12872-12881. [CrossRef] [PubMed]

13. Liu, C.B.; Li, Q.; Wang, X.; Che, G.B.; Zhang, X.J. A series of lanthanide(III) coordination polymers derived via in situ hydrothermal decarboxylation of quinoline-2,3-dicarboxylic acid. Inorg. Chem. Commun. 2014, 39, 56-60. [CrossRef]

14. Tai, X.S.; Zhao, W.H. Synthesis, crystal structure and antitumor activity of $\mathrm{Ca}(\mathrm{II})$ coordination polymer based on 1,5-naphthalenedisulfonate. J. Inorg. Organomet. Polym. Mater. 2013, 23, 1354-1357. [CrossRef]

15. Tai, X.S.; Wang, X. Synthesis, characterization and antitumor activity of a Ca(II) coordination polymer based on 3-amino-2-pyrazinecarboxylic acid. Sci. Study Res. Chem. Chem. Eng. Biotechnol. Food Ind. 2015, 16, 253-259.

16. Tai, X.S.; Zhao, W.H. Synthesis, crystal structure, and antibacterial activity of magnesium(II) coordination polymers formed by hydrogen bonding. Res. Chem. Intermed. 2015, 41, 3471-3478. [CrossRef]

17. Tai, X.S.; Wang, X. Synthesis and crystal structure of 1D chained coordination polymer constructed from $\mathrm{Ca}^{2+}$ and 2-[(E)-(2-furoylhydrazono)methyl]benzenesulfonate. Crystals 2015, 5, 458-465. [CrossRef]

18. Tai, X.S.; Zhao, W.H. Synthesis, structural characterization, and antitumor activity of a Ca(II) coordination polymer based on 1,6-naphthalenedisulfonate and 4,4'-bipyridyl. Materials 2013, 6, 3547-3555. [CrossRef]

19. Nakamoto, K. Infrared and Ramen Spectra of Inorganic and Coordination Compounds, 3rd ed.; John Wiley and Sons: New York, NY, USA, 1978; Volume 1, pp. 359-368. 
20. Jiang, D.Y.; Sui, W.; Li, X.M.; Liu, B.; Wang, Q.W.; Pan, Y.R. Synthesis, crystal structure and theoretical calculations of a zinc(II) coordination polymer assembled by pyrazine-2,3-dicarboxylic acid and bis(imidazol) ligands. Chin. J. Struct. Chem. 2016, 35, 505-513.

21. Sheldrick, G.M. A short history of SHELX. Acta Crystallogr. 2008, A64, 112-122. [CrossRef] [PubMed]

22. Sheldrick, G.M. Crystal structure refinement with SHELXL. Acta Crystallogr. 2015, C71, 3-8.

(C) 2017 by the authors; licensee MDPI, Basel, Switzerland. This article is an open access article distributed under the terms and conditions of the Creative Commons Attribution (CC BY) license (http:/ / creativecommons.org/licenses/by/4.0/). 